\title{
Decentralisation and central-local relations: The case of policing and mental health in England
}

\author{
Pre-publication version
}

$\underline{\text { To cite this article: }}$

Carlos Solar \& Martin Smith (2020) Decentralisation and central-local relations: the case of policing and mental health in England, British Politics, online first, DOI: https://doi.org/10.1057/s41293-019-00132-5 


\section{Decentralisation and central-local relations: The case of policing and mental health in England}

Over the last decade, British governments have advocated a combined policing and health policy based on the premise that everyday more people come to police attention due to mental illness issues. Central authorities emphasise co-produced local community initiatives including street triage and clinical liaison and diversion programmes as mechanism for better managing mental health issues. The model of governance of policing and mental health developed by the Conservative governments emphasises in a decentralisation of services as a means of better managing local demands. Consequently, much of the policy burden falls upon local police forces and the austerity-afflicted NHS overstressing the front lines of delivery. We argue that this rationale challenges the traditionally established model of central-local governance which saw local authorities implementing national policy. However, whilst central government has shifted responsibility for services to local deliverers, the structural and policy barriers to an integrated approach to mental health and policing have proven difficult to change when directed from the centre of government. The executive's continuous direction of policy in a climate of austerity politics triggers not only a debate on the sustainability of local governance, but also with regard to what power of delivery local institutions have. We conclude that the nature of governmental decentralisation on cross-sectorial policymaking can jeopardised the creation of sustainable local governance practices.

Keywords: austerity, decentralisation, central-local governance, police, NHS. 
Central-local relations in the UK have been an issue of contention for most of the post-war period. After a long period of centralisation -particularly during the Thatcher governmentthere has been a recognition by all main parties of the need to reinvigorate local government. Recently both the devolution agenda and austerity economics have seen a significant attempt to shift responsibilities for key policies to local government. The Conservative-Liberal Coalition (2010-2015) and the succeeding governments of David Cameron and Theresa May pushed for a model of central-local governance that relies heavily in improving quality of services while keeping costs down (Lowndes and Gardner, 2016). Hence a policy of austerity has been accompanied by an increasing focus on local delivery (see Diamond, 2015). Consequently, local services have set up initiatives to manage a growing demand in their capabilities, although, with a smaller workforce and less resources at hand.

In this article, we question the current model of austerity-driven decentralisation reform and suggest that this has brought unexpected outcomes for local institutional accommodation. We use the policing and mental health sectors as case studies to explore how recent decentralisation policies have created complex relations of co-production and inter-agency at the local level, shedding light on what the effect has been for central-local relations. The problem is that in many ways the institutional arrangements at local level make it difficult for agencies on the ground to respond in ways that the centre expects. The capacity for joined up delivery is weak at local level because most institutions, whether it is the police or health authorities, respond to national requirements.

On the one hand, central government has tried to tackle complex issues like mental health through supporting local initiatives. Policies have attempted to create local network such as the police forces and the NHS, to work with newly established ones including the Office of the Police and Crime Commissioner (PCC) and the Clinical Commissioning Groups (CCGs). Governments have funded policy programmes, such as, 'No Health Without Mental Health' 
(HM Government, 2011), and the 'Mental Health Crisis Care Concordat' (HM Government, 2014a). Since 2013, street triage pilots (a service where mental health nurses accompany officers to incidents where police believe people need immediate mental health support), have been implemented in almost all regions of England, following the Coalition's plans to keep people out of custodial settings and reduce the demands on police time (HM Government, 2013). However, we argue that these and other service reforms towards a limited state have resulted in a dramatic reduction of local capabilities, especially in the welfare policy areas, including the policing and health (Evans, 2010; Smith and Jones, 2015). Police forces and the NHS have been victim of reductions to its services and personnel (Reiner, 2016; Heslin et al., 2016). Not less relevant, fiscal cuts to spending in these two sectors have not always been wellreceived by the users and the overall public (Clarke, et al., 2013).

We begin the paper by presenting a conceptual approach to central-local relations. We use this theoretical framework to provide a lens through which to understand the governance changes in policing and mental health policy as a result of decentralisation. We then provide empirical evidence on policing and mental health governance reforms. The article explores how the pulling together of these two sectors has fallen prey of unintended consequences due to an incongruent steering from the centre. In the analytical section, we argue first that certain structural and policy barriers to an integrated approach in local policing and mental health governance have proven difficult to change when directed from the executive. Second, we propose that continuous policy change in a post-crisis climate has triggered not only a debate on whether local governance is a sustainable response to such a demand for outputs, but also on what delivery powers local institutions have. Third, we reflect on the idea that while public institutions are protecting themselves from risk and further budgetary cuts, the lack of the necessary powers to address complex corporate differences has put local policy communities 
at a crossroad. We conclude by examining the current trade-off between decentralisation, austerity, management capabilities, and central-local governance issues.

\section{Decentralisation and central-local relations}

Changes occurring in local government have highlighted the difficulty of adjusting service delivery to fluctuating sources of national funding. Recent scholarship has emphasised on the necessity of institutional resilience among local public services in order to endure austerity (Gardner, 2017; Rex, 2019). To some scholars, the new wave of decentralized decision-making has prompted large and small administrative units to restructure, yet, in many places, the reshuffling of people and resources strays little from existing arrangements (Richardson, Durose and Dean, 2018). Wilson and Game (2011), for example, identified three models that explain these processes of adaptation: power dependence, mostly following Rhodes (1988), principal-agent relations, brought forward, for instance, by Lane (2006), and network governance approaches frequently used by scholars studying macro, meso, and micro levels of policymaking (see, Klijn and Koppenjan, 2016; Bailey and Wood, 2017).

At one level, the UK's post-1945 situation can be described one of power dependence where, as Rhodes (1988) points out, whilst the centre was formally in control, its dependence on local government for delivery made the relationship complex. The Thatcher administration attempted to assert a principal-agent model with local authorities either by-passed or seen as agents delivering central government policy. More recently with a reaction against centralised governance there has been a focus on partnership and devolution leading to the creation of complex networks for policy delivery. However, whilst there seems to be a chronological development due to institutional layering (Thelen, 2009), the case is that in UK all three models have been used interchangeably. We argue that the relationship between the centre and local agencies is often contingent and includes elements of dependence, hierarchy and networks. 
The key issue has been that an agenda of decentralisation has been developed not as a mechanism of local accountability or democracy but as a means for reducing funding. For example, in April 2015, one month before the general election in which Cameron won the reelection, Theresa May, the then Home Secretary, announced further cuts to police budgets across the country despite police personnel forecasting a worsening of services if resources were to disappear (Morris, 2015). Local agencies have functioned as mechanism for depoliticising austerity through what Bulpitt (1983) calls the dual polity by shifting responsibility for declining services from national to local level. The government cuts spending and placed the onus of reform on local agencies to maintain services with restricted budgets (Diamond, 2014; Griffiths, 2009). For example, the executive legitimised decreases in the police force by arguing crime continued to fall in the UK (Newburn, 2015).

At the same time the Coalition government, for example, pushed forward its public services programme on the notion 'that it was time to disperse power and hand it back to the people and communities' (Benyon, 2011). In the context of economic crisis, the focus of policy was on the need to reduce what was perceived as an expensive and inefficient centralised state. The Coalition Government's model of strict cost-containment was based on the ethos: 'do better, with less'. The rationale behind it implied that public services could provide the same level of service with less money and so invoking Thatcherite New Public Management (NPM) of strong 'managerialism' through a 'hard-headed, business-minded, cost-conscious, and datadriven approach to government makeover' (Hood and Dixon, 2015, p. 15).

Government focussed on the costs of policy whilst letting governing responsibilities fall to local authorities who became responsible for delivering core services with much less money. As O'Driscoll argued, 'responsibilities for policymaking in the communities have encouraged regional stakeholders to form groups to develop local policies, in response to national policies' (2007, p. 124). While at the core of the Big Society rested on the reduction of the state -at 
whatever unorthodox means- the overall strategy for cutting public spending meant more social enterprise and more private sector dependence for societal service delivery (Smith, 2010; see also Kerr and Hayton, 2015; Dommett, 2015).

The Conservative governments post austerity local policy framework reflects a network governance model (see Bevir and Rhodes, 2016) but with more focus on central control than would be normally assumed within this approach. For example, the Coalition created a network encompassing police, local authorities, and public health services around the Mental Health Crisis Care Concordat, a joint statement to co-produce mental health and safety policies between services. The concordat came to recognise the "concerns about the way in which health services, social care services and police forces work together in response to mental health crises' (HM Government, 2014b).

Reveruzzi and Pilling (2016), argued, nonetheless, that decentralised network governance produced a sense 'frustration for delegated governance' (see on such issue Dommett and Flinders, 2015) among local service when evaluating the mental health concordat. They described such discontent in these terms:

Although the provision of mental health crisis interventions initiated through contact with the police or other members of the emergency services is not a preferred route into care, it is widely recognised that police officers remain a gateway to care for some people in crisis. (...) police officers have often experienced difficulty in gaining an adequate response from local health and/or social care agencies. These problems can be exacerbated by the reluctance of some agencies to share information about the person in crisis and an unwillingness on the part of some services to accept referrals from police officers (p. 11). 
For the local institutions, a flawed network governance has occurred as a result of various structural, budget, and power relations. Because of a limited capacity for tax collection, for instance, local governance autonomy from government is limited (see Stoker, 2011; Hood and Dixon, 2015). Since the Coalition era, the central authorities have encouraged public institutions to reform their administrations (mostly getting rid of costly services), and not less, seek support from private actors (Page, 2011). Services have been decentralised but without providing either the resources or the governance structures to ensure effective delivery. As Lowndes and McCaughie (2013) put it, the conservative's decentralisation and interinstitutional network governance agendas has yet not come up to expectations, less so in the context of post-financial crisis austerity. Andrews and Entwistle (2015) noted that interinstitutional partnering do not necessarily improve the quality services, less so if they are left to their devices. For policy communities and networks to be successful, they need steering and also costing management capacity, however, in this case, this role is performed by overstressed local public administrators.

The problem in the UK is that the relationship between the centre and local has always been contested. Different models of relationships have been used but often they have been implicit rather than explicit. There has always been an asymmetry of power (Marsh, Richards and Smith, 2003) with the centre dominating, but, the nature of the asymmetry has varied. Consequently, power dependence, principal-agent and network models have built on, rather than replaced, each other.

In sum, we argue that recent decentralisation reforms in the advanced democracies have triggered unexpected outcomes for local governance. The interplay between the reduction of central top-down accountabilities and the lack of steering has been critically stressed by the recent era of economic austerity (Ansell and Torfing, 2014; Davies and Thompson, 2016). A new responsibility for service delivery within the context of restrained resources has been 
placed on local government and agencies which has created particular strains in the delivery of local services. In the next section, we use the policing and mental health sectors to explore recent complex co-production and inter-agency at the local level, and their effect upon centrallocal relations.

\section{Reforming the police: funding, accountability, and mission}

The period since 2010 has seen considerable reforms in governance in areas ranging from criminality and the rule of law, to the pensions system and the environment (Richards, Smith, and Hay, 2014; Berry, 2016; Carter and Clements 2015). Within this context there has been a considerable change in the role of the police with an increased focus on "partnership, cofunding, and co-production, but that rejects the binary proposition that the state spends too much' (Griffiths and Kippin, 2013, p. 12). Under New Labour, government prioritised tackling anti-social behaviour, and augmented police spending to resource reforms including an increase to statutory local policy networks for partnership working, and a national model of community support through civilian neighbourhood policing (Squires, 2008). However, the Coalition and the succeeding Tories governments emphasised in a model that placed localism within a national regulatory framework with the reform of national organisations, introducing a new non-ministerial department, the National Crime Agency, along other initiatives such as the College of Policing, and the PCCs.

Cameron and later May’s agent-based agenda for decentralisation, for instance, created scorn among police personnel who saw budget cuts as reducing operational capabilities and an intrusion to their professional autonomy (see Bayley and Stenning, 2016). The period following 2010 saw a $20 \%$ real term cut in central government funding. A decreasing trend in the numbers of police officers in England and Wales lowered the workforce from 171,600 in 2010, to 
123,171 in March 2019. Police community support officers (PCSO) added to 9,547, a negative 5.8 percentage change in relation to 2018 (Home Office, 2019).

To some observers, the Government's reforms pointed towards a power-dependence governance model with the regions that resulted in 'a much less comfortable relationship between the government and the police service' (Newburn, 2015). Sarah Thornton, who was appointed to lead the National Police Chiefs' Council (NPCC) in July 2015, argued that the police system needed to go under a 're-imagination' process as an expected loss of 35,000 police posts by 2020 is a 'game-changer' (Shaw, 2015). A few days before Thornton's comments, Theresa May had told the Police Federation to stop 'crying wolf' about the impact of financial cuts, accusing the leaders of the body of 'scaremongering' over the effect of cuts while crime was falling (BBC, 2015).

Across England, cuts have produced a closure of police stations and a reduction of opening hours at others. Since police is retreating from interaction with local users, the remaining points of contact are saturated by the same, or even increasing demand of emergencies. Cuts to police funding from central government became so critical by 2015 that even Cameron's constituency in Oxfordshire was meant to cut $£ 60$ million in police force savings triggering allegations from local representatives (Hopkins, 2015).

Mental health crises, on the other hand, mean a continuous rise of people depending on contacting the police first before being referred to the adequate expert health services. Recent data compiled from 35 forces in England, Wales and Northern Ireland showed that police are spending as much as $40 \%$ of their time dealing with incidents triggered by some kind of mental health issue. Also, the overall number of incidents with a mental health aspect rose by $33 \%$ between 2011 and 2014 (Quinn et al., 2016). In this vein, a report by the Home Affairs Committee in the House of Commons reported that one in four people will suffer from mental health illness at some point, and their illness brings with it a vulnerability that makes it likely 
they will come into contact with the police (House of Commons, 2015, p. 7). The report goes on to argue:

For many people experiencing an acute health crisis, a police officer is not the professional best placed to help them, nor is dealing with acute health crises the best use of police officers' time and skills. We believe that the police should not be filling gaps in mental health services (House of Commons, 2015, p. 8).

The Coalition's programme (2010) promised to end top-down government and promote decentralisation by encouraging a power-based model to local governance under the adage 'devolving power from the centre' (see Travers, 2015). Cameron, and May later instituted an agenda of mixed resource allocation, pushing forward the idea that police needed to become more specialised with fewer staff. Through a central-local relation based on policy networks and partnership boards, police personnel became able to take a leading role in the co-delivery of mental health services so to improve the experience of individuals in crisis. This happened mostly as police forces across the country joined multi-agency experiences that develop strategic oversight, assigned operational responsibilities and processes, and established clear crime prevention and care pathways. Police personnel was exposed to deal with new challenges regarding the rule of law through a discretionary risk-based rationale. On the other hand, mental health issues demanded flexible horizontal interaction with partner agencies, most notably the health services from the NHS, posing a challenge to what hierarchic British policing has been over the last decades. 


\section{Reshaping mental health policy}

One of the cardinal questions regarding health policy by 2010 was what future there was for a multi-expert and patient-centred NHS. The health policy sector and particularly mental health practice was so vast and complex in England, that effective governance was deemed a complicated business (Tempest, 2006). During New Labour, mental health policy was characterised by questions of how to set up structures and processes, institute professional jurisdictions, and how create sustainable links with the wider health and welfare policy sectors (Pilgrim and Ramon, 2009). Practical decision-making, multi-disciplinary working and team management engrained as three concepts that health practitioners became constantly challenged with (Ovretveit, Mathias and Thompson, 1997). Were these complexities taking into consideration by more recent governments when reshaping mental health governance policy? Most probably yes. However, did this reflect in the executive's decentralisation policy since 2010? Here the answer is less clear. For instance, Andrew Lansley, who was Shadow Secretary of State for Health and later sat in government with Cameron, set the tone back in 2006 for what was to come: 'standardisation across the NHS would derive not so much from political or managerial requirements as from clinical needs for reliability and quality' (Lansley, 2006, p. 23). Unluckily, mental health practices have resulted far from equal since 2010 as NHS Trusts and Clinical Commissioning Groups (CCGs) across England share scarce managerial guidelines outside their corporate remits (Mattheys, 2015).

Through a power-dependence type of central-local relation, government introduced in February 2011 the 'No Health Without Mental Health' strategy co-signed between Secretary Lansley and Paul Burstow, Secretary for Care Services. In it, government stressed its view on how 'action at local and national levels to implement this strategy will only be effective if there is sustained partnership working across all sectors' (HM Government, 2011, p. 68). The document also argued the following: 
the costs of mental health problems to the economy in England have recently been estimated at a massive $£ 105$ billion, and treatment costs are expected to double in the next 20 years. We simply cannot continue to allow costs to spiral upwards without ensuring that every pound of public money is being used efficiently (HM Government, 2011, p. 2).

Elusive public spending and more power into people's hand at the local level were the two key drivers of the strategy, certainly a formula that echoed with the overall reform to the NHS.

In the Coalition government, conservatives and liberal democrats took the flag of mental health supporting various initiatives. Deputy Prime Minister, Nick Clegg, called for people to nominate unsung mental health heroes 'to celebrate those from every region - from healthcare professionals to next door neighbours - who have gone above and beyond to help, support or inspire people with mental health conditions' (Office of the Deputy Prime Minister, 2015). Driven by hard data, government used a set of statistics to push mental health on to the top of government's to-do list.

Deputy Prime Minister, Nick Clegg launched in late 2014 the UK's first Mental Health Taskforce promising important monetary resources to initiatives such as treatment and therapies for children and young adults. In Parliament, conservative MP Gavin Barnwell's advocated to reform the Mental Health (Discrimination) Bill intended to reduce stigma and negative perceptions associated with mental illness. A public opinion survey showed by then that $67 \%$ of British adults believed people with mental health problems were discriminated against. The mentally ill were more widely seen as discriminated against than gypsies and travellers, transsexuals, immigrants, Muslims or disabled people (YouGov, 2013). 
Civil society became part of the discussion as well by reviewing mental health policy and producing critical insights. The Royal College of Psychiatrist (RCPsych) published a document entitled 'No Health Without Mental Health: the Supporting Evidence', in which it outlined five key areas to strengthen policy, including: introducing screening services in acute hospitals and annual checks to patients; funding liaison mental health services in all hospitals; engaging patients and carers through information and education; re-organising commissioning and quality standards supervision; and, enhancing training in mental health in all health practitioners (RCPsych, 2010). Government's and the RCPsych's reports demanded for new resources to be created, however, making little resemblance to the austerity policy previously determined by the executive under the post-crisis fiscal plans. The reduction of public spending was forecasted by the policy community. Although health, pensions, and education were considered 'protected' expenditure (all three amounted for up to $44 \%$ by 2015 in government spending on services), the health sector has since faced the most austere cutbacks in the postwar period (Parliament, 2015)

Yet, the NHS was said to have reacted efficiently to the cuts by increasing its quantity of care provided. Government's 'do more, with less' agent-type of maxim proved, to some observers, partly successful as 'waiting times for inpatient and outpatient care remained low, rates of hospital acquired infections continued to fall, public satisfaction was historically high, and most patients continued to report a positive experience of care' (Parliament, 2015). However, areas such as hospital admissions saw a rising trend, and bed availability, particularly in mental health units, was 'increasingly limited and the financial position of NHS providers is also worsening, indicating that some were struggling to cope with the reduced prices paid for services' (Parliament, 2015).

\section{Decentralisation's unexpected outcomes}


Unless properly corrected by the current and succeeding UK governments, those having a mental illness and coming across with the police will have a better opportunity in richer and more resourceful areas that those in the poorest and most afflicted ones. In this sense, the austerity-driven restructuring of mental health services across England has already found resistance campaigns that feature alliances between service users, workers, trade unionists and anti-cuts activists (Moth, Greener and Stoll, 2015). Against this backdrop, we argue that at least three challenges need to be considered in this current wave of decentralisation reform: structural barriers to integrated polity, post-financial crisis policymaking, and the degree of differentiated corporate policies.

\section{Structural barriers to integrated polity}

Empowering local governance has put the police and the mental health NHS emergency services to reach networked multi-agency solutions to issues that were once dominated by silomaking type of solutions (see Smith et al., 2011). However, it is argued that structural barriers to networks have not meant for professional thinking to allow inter-institutional and integrated policy-making when it comes to strategic, operational and frontline responses. Returning to the House of Common's report, a paragraph within its final recommendations sheds light on these matters:

The coalition government has recognised the poor state of current mental health services and it has made a commitment to put mental health at the same level as physical health. In addition to resources, there is a clear need for improved coordination between the organisations that come into contact with mental health sufferers. The Concordat has shown potential for bringing the relevant organisations together. Its success will be measured by how effective it is in those areas of the country where such relationships 
are not well developed, where there is an absence of local leadership, and where the commitment to addressing the issues is absent (House of Commons, 2015, p. 36).

The Mental Health Act of 1983 is the current guideline used to measure police responses to crises in mental health. Police officers in England enforce Section 136 of the code that allows them to take a person to a place of safety (usually where NHS professionals would take charge of matters) if there are concerns that requires immediate care or control in their own best interests or for the protection of others. If the number of detentions under Section 136 decrease, fewer people will most probably be held in a police cell where they are more sensitive to experience the trauma of being detained (Care Quality Commission, 2015; HM Government 2014b). The House of Commons' report proposed a change in the law so that police cells are no longer a 'place of safety' under the Mental Health Act (House of Commons, 2015, p. 9-15). On these matters, the conservative governments and the police have aligned. Theresa May delivered a speech in Westminster where she catalogued the issue of policing and mental health as 'stubborn', 'hard to resolve', 'difficult to spot' and 'often neglected'. When it came specifically to the Section 136 issue, Theresa May argued the following:

Imagine being transported to hospital not in an ambulance, but in the back of a police car. Or being detained in a police cell rather than a health-based place of safety or mental health ward. That encounter must be terrifying. The police are not medics. They are not mental health nurses. They are not social workers. But if the relationship between the police and the public is critical, then how the police and other agencies respond to vulnerable people is even more important still. It goes right to the heart of the British model of policing by consent (HM Government, 2014c). 
The Home Office produced a 30-page 'response' to all of the 29 conclusions and recommendations made by the House of Commons (Home Office, 2015). Setting a tone of what government policy was all about, it argued, that government 'has made clear that it is determined to remove the police from unnecessary or inappropriate involvement in what should primarily be a medical response' (p. 3). Regarding detentions under Section 136, the document explicitly mentioned,

In general, the overuse of police cells for people detained under section 136 reflects probable deficiencies in the service provision available from a number of local agencies. There are numerous reasons for police cells having been used too often, and these include local health-based places of safety lacking the necessary capacity, or refusing to accept the person for being intoxicated and/or bringing a real (or perceived) threat of violence. The overuse of cells may also have been influenced by some unnecessary use of section 136 by police officers, and lack of availability of Approved Mental Health Professionals (AMHPs) (p. 4).

However, accountability to the current structure of British policing and mental health is quite limited. Section 136 detentions have shown to go down after street triage initiatives have been set up. However other underlying structural pillars have not. The budgetary demands of street triage and health liaising with the NHS suggested by the Bradley Report (2009) and the Independent Commission on Mental Health and Policing (2013) have proven to add little value for money (Heslin et al., 2016).

Police forces have fought back budgetary cuts beckoning that their services have improved. The number of Section 136 detentions have increased in England and Wales, from 
23,859 detentions in $2016-17$ to 25,143 in $2017-18$. Although the reasons for its increase remain to many unclear (see Loughran, 2018; Thomas and Forrester-Jones, 2019), this data should be contextualised since a high number of mental health incidents do not end in a detention under Section 136. Also, a number of cases where police is spending resources are not being taken into consideration (for example, calls to the force control room that do not need police deployment or police attendance to events where people is later referred to other services). In this vein, a National Institute for Health Research report reviewing evidence on the outcomes for people in mental health crisis, concluded that there is little evidence to identify what works best to improve integrated urgent and emergency access to crisis care to guide police officers through the Mental Health Act responsibilities (Paton et al., 2016). Another report, published this time between the NHS' Mental Health Network and the Association of Chief Police Officers diagnosed, in the same vein, that police, mental health services, local authority, A\&E, and ambulance often only 'sit and discuss' issues raised by multi-agency working and how to resolve these (NHS Confederation, 2015). Nevertheless, inter-agency has not fully avoided that too many people in mental health crisis have been detained in police custody when they need urgent mental healthcare instead, nor has the police and mental health providers established a clear understanding of each other's legal powers, roles and responsibilities (NHS Confederation, 2015, p. 1; Adebowale, 2013).

\section{Post-financial crisis policymaking}

Shortly after being re-elected in 2015, Cameron set out his plans for a seven-day NHS arguing his 'commitment to free healthcare for everyone', saying that his defectors had talked 'a lot of rubbish' about his policy programmes under austerity. 'So first of all today I want to put the record straight loud and clear. They said we would cut the NHS. We haven't and we won't', Cameron insisted (Prime Minister's Office, 2015). Backing up his policy proposals resulted in 
a wave of new funding for the local services although only disperse actions for delivery were outlined. A pool of $£ 12$ million was promised to expand services for mental health assessments to those arrested. According to government data, at least 50,000 people a year are assessed by liaison and diversion services following arrest, and almost $70 \%$ require mental health support (Department of Health, 2016). As well, another $£ 15$ million was granted between the Department of Health and the Home Office to provide health and community based places of safety across England to prevent vulnerable people being held in police cells. Government opened biddings in various priority areas where the use of police cells was amongst the highest, including Avon and Somerset, Cleveland, Derbyshire, Devon and Cornwall, Essex, Lincolnshire, Nottinghamshire, South Yorkshire, Sussex and West Yorkshire (Department of Health and Home Office, 2016). Open funding aimed to get co-sponsored applications between police, health and from other organisations, including health trusts, local authorities and the third sector. The move put the NHS and the police to work under shared budgets and collaborative processes of policy delivery. Truth is that so far there has been little evidence on the efficiency, for instance, of a non-traditional provider of places of safety. The Home Office, for instance, insisted in the specific case of a third sector-led scheme to trial an alternative place of safety in Sussex to offer a temporary safe and secure room to individuals brought to by the police or ambulance service (Richmond Fellowship, 2016). Such initiatives followed on the spirit of the Health and Social Care Act 2012 which provided with guidelines to resolve health matters through ring-fenced grants and funding with local accountability arrangements.

In summary, although mental health and policing decentralised planning under Cameron was grandiose, at the end of the day policy-making and its delivery occurred at the local level through existing institutional arrangements. The scale reduction from national to local governance (see Ansell and Torfing, 2015) has created central guidelines that need to travel to local scattered nodes for policy that with time have become self-reliable and financially 
independent. Nonetheless, these have not grown equally nor at the same pace around England. Some have developed more complex economic policy models, while others stick to older models to respond to ad-hoc emergencies with limited monetary resources.

\section{Differentiated corporate policies}

Succeeding decentralisation policies have failed to see the endogenous capabilities for change that complex institutions confront as central government promotes local governance reform (see Lowndes and Lemprière, 2018). This has been evidenced mostly after the centre's attempt to steer policymaking through what we interpret as agent and power-dependence approaches to central-local relations. In the health sector, for example, the local chapters of the NHS had historically seen a group of different interests from within it, such as the divisions between primary and secondary care, and general and specialist practitioners. On the other hand, in the policing sector, the reduction of the workforce came together with changes from within as duties allocated to police personnel sought to reorganise and break down barriers of traditional policing and risk-aversion assessments. Police forces around the country were centrally directed to ground-breaking partnerships with the health sector under novel rationales to vulnerability through a non-prosecutorial approach. Ian Blair, former commissioner of the Metropolitan Police, put it this way:

The police and hospital A\&E units have, in the past decade, become the only 24-hour public services for people in crisis. The police have had severe funding cuts but are still there at the end of a telephone. Anyone working in the NHS will admit that the government's vaunted "parity of esteem" between physical and mental health has not been honoured, particularly for young people. Meanwhile local authority budgets, 
which part-fund child and adolescent mental health service and community health teams, have not been protected at all (Blair, 2016).

There are lessons to be learned, nevertheless, as the complex new field of policing and mental health remains a puzzle for government when understood as the sum of its parts. For instance, street triage services and clinical liaison and diversion, among others, will continue to be the word of the day in policing and mental health services. Despite the apparent centralisation of the UK, these initiatives have developed in very different ways in each of England's regions and very much in accordance to what police forces and other regional agencies have to offer in terms of funding, structure, human and capital resources.

Government's further budget reductions stretching until 2020 were in part determined to end Tony Blair's centralised performance management for the health sector. Cameron came to introduce a freer competition system with independent regulation in a second White Paper that set out the executive's public health strategy (Department of Health, 2010). What this approach did not contemplate, however, was that policy planning and policy delivery where being formulated under two very different premises. Policy planning opted for a no extra budgets, whilst the delivery included a vast array of mechanisms that required funding. A Freedom of Information request by the BBC, showed that the budgets for mental health trusts fell by 2\% from 2013-2014 to 2014-2015. According to the data, '53 out of 59 mental health trusts in England which responded to the FOI request, 29 said their budget would be lower this year than last' (Bloch, 2016). Local authorities saw prevention budgets recede thus truncating the opportunities for mental health care to be delivered outside hospital units making a policy network governance approach across local health and non-health related institutions much less likely to succeed as a real alternative to traditional hospital services. 
Although decentralisation and localism were meant to occur naturally and according to local realities, cross-sectoral issues such in local policing and mental health seem to cut through the isolation that local governance produces. Whilst for police it has become key to getting services across their regions in a cohesive and efficient form, often police forces only develop products for certain communities. Consequently, even within the same region there can be differentiated services for their communities. The same happens in the health sector where the NHS is divided in different clinical providers and commissioning groups. On top of that, local services don't have the same geographical remits most of the times overlapping dense areas where demand is greater, leaving less populated ones in hands of fewer services.

\section{Conclusion}

Decentralisation under austerity has brought local services together, however, we have argued that central-local relations have not necessarily benefited the on-going local inter-institutional governance in the areas of policing and mental health. Through promoting decentralised local governance, the executive hoped for the delivery and steering of resources to meet the needs of local vulnerable communities. However, issues beyond the control of the local policing and mental health agencies have stalled decentralised governance, in this case, what we proposed as structural barriers, receding budgets, and the evidence of differentiated powers across policy sectors to encourage engagement between local autonomous corporations, such as the police forces and the NHS.

In light of the reduction of central government's role in steering on-the-ground policies, for example, on the case of mental health and policing a set of horizontal arrangements have begun as a response to the ongoing budget cuts, however, there is stress in the structural system because of a lack of clear strategic direction happening under the de-centralisation paradigm; this time worsened when factoring in the effects of the policymaking under austerity and 
cutbacks measures. For instance, the creation of the local PCCs in England and Wales attempted to solve local governance and accountability issues by giving them statutory powers enforcement and budgetary responsibilities that police forces could depend on to co-finance services (Lister and Rowe, 2015). However, we have argued that the current financial model for local governance seems to be outmoded. Previously, if local authorities had more political responsibility of the policymaking without central steering, they would arrange higher taxation schemes to cover for such delivery costs (Stewart, 2000; Stoker and Travers, 2001). Currently, and like the policing and mental health case study showed, central government frames the policy agenda, however, it does not necessarily distribute monetary resources. Local authorities on the other hand, have had their tax collection and budgets reduced, however, they have been empowered with more responsibilities in planning service delivery. Moreover, local policymakers are encouraged to engage in public-private partnerships through a networked type of central-local relations. However, for these to results in efficient public services delivery, they need to be steered by a demanding and also costing management capacity. This latter idea was argued by Andrews and Entwistle (2015), who indicated that public-private partnerships do not necessarily improve the quality of services, less so if they are left to their own devices.

Local governance networks are having to fill the vacuum of authority left by decentralisation, developing new mechanisms for steering policy. For the case of the mental health and policing combined policy sector, it is difficult to forecast from where the power to enforce such relationships will come. Also, if institutions will abide in light of the myriad of heavy weight actors (such as the NHS, the PCCs, and the police forces) who are currently interlinked in different areas of public service, and not just in the mental health one. Without an overall agent authority, local actors make autonomous decisions which undermine attempts for networked partnerships. For instance, there are many problems over data sharing (even within organisations), for example, due to police having different systems for recording mental 
health incidents and users involved to those used in the NHS. In the overall security and welfare sectors, there are also significant overlaps of service provision spatially and a lack of clarity in terms of who has responsibility on moments of crises, something that decentralisation has made more evident lately. As seen in the police and mental health case, attempts to reconfigure local services ultimately shift patterns of demand without shifting structures, budgets, or joining differentiated corporate powers, which result in local agencies making huge efforts to remedy increasing management capacities.

\section{References}

Adebowale V. (2013) Independent Commission on Mental Health and Policing Report. Retrieved from http://news.bbc.co.uk/1/shared/bsp/hi/pdfs/10_05_13_report.pdf (Accessed 28 June 2016).

Andrews, R. and Entwistle, T. (2015) Public-private partnerships, management capacity and public service efficiency. Policy \& Politics 43(2): 273-290.

Ansell, C. and Torfing, J. (2014) Public Innovation through Collaboration and Design. Abingdon: Routledge.

Ansell, C. and Torfing, J. (2015) How does collaborative governance scale? Policy \& Politics 43(3): 315-329.

Bayley, D. H. and Stenning, P. C. (2016) Governing the Police: Experience in Six Democracies. New Brunswick and London: Transaction Publishers. 
Bailey, D. and Wood, M. (2017) The metagovernance of English devolution. Local Government Studies, 43(6): 966-991.

BBC (2015) Police Federation crying wolf over cuts, says Theresa May. BBC News, 20 May 2015, http://www.bbc.co.uk/news/uk-32806520, accessed 18 June 2016.

Benyon, J. (2011) The Con-Lib Agenda for Home Affairs. In: S. Lee and M. Beech (eds.), The Cameron-Clegg Government: Coalition Politics in an Age of Austerity. Basingstoke: Palgrave Macmillan, pp. 134-152.

Berry, C. (2016) Austerity, ageing and the financialisation of pensions policy in the UK. British Politics 11(1): 2-25.

Bevir, M. and Rhodes, R.A.W. (2016) Rethinking Governance: Ruling, Rationalities and Resistance. London and New York: Routledge.

Blair, I. (2016) The police can't continue to pick up the pieces of Britain's mental health cuts. Retrieved from https://www.theguardian.com/commentisfree/2016/oct/25/police-britainmental-health-cuts-crisis, accessed 01 November 2016.

Bloch, S. (2016) NHS mental health funding falls in England. BBC News, 14 February 2016, http://www.bbc.co.uk/news/health-35559629, accessed 28 June 2016.

Bradley, K. (2009) The Bradley Report: Lord Bradley’s Review of People with Mental Health Problems or Learning Disabilities in the Criminal Justice System. Retrieved from http://www.rcpsych.ac.uk/pdf/Bradleyreport.pdf (Accessed 28 June 2016). 
Bulpitt, J (1983) Territory and Power in the United Kingdom: An Interpretation. Manchester: Manchester University Press.

Carter, N. and Clements, B. (2015) From 'greenest government ever' to 'get rid of all the green crap': David Cameron, the Conservatives and the environment. British Politics 10(2): 204-225.

Clarke, Harold D., Borges, Walter, Stewart Marianne C., Sanders, D. and Whiteley, Paul (2013). The Politics of Austerity: Modelling British Attitudes Towards Public Spending Cuts. In: N. Schoefield, Norman, G. Caballero, D. Kselman (eds.) Advances in Political Economy: Institutions, Modelling and Empirical Analysis. Berlin and Heidelberg: Springer, pp. 265-288.

Davies, J. S. and Thompson, E. (2016) Austerity realism and the governance of Leicester. In: Mark Bevir and R.A.W. Rhodes (eds.) Rethinking Governance: Ruling, rationalities and resistance. Abingdon and New York: Routledge, pp. 144-161.

Department of Health (2010). Healthy Lives, Healthy People: Our Strategy for Public Health in England. Retrieved from https://www.gov.uk/government/uploads/system/uploads /attachment_data/file/216096/dh_127424.pdf (accessed 28 June 2016).

Department of Health (2016). Increased mental health services for those arrested. Retrieved from https://www.gov.uk/government/news/increased-mental-health-services-for-thosearrested (accessed 18 July 2016). 
Department of Health and Home Office (2016). Retrieved from https://www.gov.uk/government/news/new-funding-for-safe-places-for-people-in-mentalhealth-crisis (accessed 18 July 2016).

Diamond, P. (2014) Governing Britain: Power, Politics and the Prime Minister. London: I.B. Tauris.

Diamond, P. (2015) New Labour, politicisation and depoliticisation: The delivery agenda in public services 1997-2007. British Politics 10(4): 429-453.

Dommett, K. (2015) The Theory and practice of party modernisation: The Conservative Party under David Cameron, 2005-2015. British Politics 10(2): 249-266.

Dommett, K., and Flinders, M (2015). The centre strikes back: meta-governance, delegation, and the core executive in the United Kingdom, 2010-14. Public Administration 93(1): 1-16.

Driver, S. (2011) Welfare reform and Coalition politics in the age of austerity. In: S. Lee and M. Beech (eds.) The Cameron-Clegg Government: Coalition Politics in an Age of Austerity. Basingstoke: Palgrave Macmillan, pp. 105-117.

Evans, M. (2010) Cameron's competition state. Policy Studies 31(1): 95-115.

Gardner, A. (2017). Big change, little change? Punctuation, increments and multi-layer institutional change for English local authorities under austerity. Local Government Studies, 43(2): 150-169. 
Griffiths, S. (2009) Cameron's conservatives and the public services. In: S. Lee and M. Beech (eds.) The Conservatives under Cameron: Built to Last? Basingstoke: Palgrave Macmillan, pp. 97-108.

Griffiths, S. and Kippin, H. (2013) Introduction. In: S. Griffiths, H. Kippin and G. Stoker (eds.) Public Services: A New Reform Agenda. London and New York: Bloomsbury, pp. 1-15.

HM Government (2010). The Coalition: Our Programme for Government. Retrieved from https://www.gov.uk/government/uploads/system/uploads/attachment_data/file/78977/coalitio n_programme_for_government.pdf (Accessed 28 June 2016).

HM Government (2011). No health without mental health: A cross-government mental health outcomes strategy for people of all ages Retrieved from https://www.gov.uk/government/uploads/system/uploads/attachment_data/file/213761/dh_12 4058.pdf (Accessed 28 June 2016).

HM Government (2013). Extending the street triage scheme: New patrols with nurses and the police. Retrieved from https://www.gov.uk/government/news/extending-the-street-triagescheme-new-patrols-with-nurses-and-the-police (accessed 27 June 2016).

HM Government (2014a). Mental Health Crisis Care Concordat Improving outcomes for people experiencing mental health crisis. Retrieved from http://www.crisiscareconcordat.org.uk/wp- 
content/uploads/2014/04/36353_Mental_Health_Crisis_accessible.pdf (accessed 27 June 2016).

HM Government (2014b) Review of the Operation of Sections 135 and 136 of the Mental Health Act 1983: Review Report and Recommendations. Retrieved from https://www.gov.uk/government/uploads/system/uploads/attachment_data/file/389202/S135_ and_S136_of_the_Mental_Health_Act_-_full_outcome.pdf (accessed 01 November 2016).

HM Government (2014c) Home Secretary at the Policing and Mental Health Summit. Retrieved from https://www.gov.uk/government/speeches/home-secretary-at-the-policing-and-mentalhealth-summit (accessed 28 June 2016).

HM Government (2016). PM: Improve mental health treatment to get thousands more back to work. Retrieved from https://www.gov.uk/government/news/pm-improve-mental-health treatment-to-get-thousands-more-back-to-work (accessed 27 June 2016).

Home Office (2019). Police workforce, England and Wales: 31 March 2019. Retrieved from https://www.gov.uk/government/statistics/police-workforce-england-and-wales-31-march2019

Hood, C. and Dixon, R. (2015). A Government that Worked Better and Cost Less? Evaluating Three Decades of Reform and Change in UK Central Government. Oxford: Oxford University Press. 
Hopkins, N. (2015). Police cuts: David Cameron tried to save constituency stations. BBC News, 13 November 2015, http://www.bbc.co.uk/news/uk-politics-34815792, accessed 28 June 2016.

House of Commons (2015). Policing and Mental Health. Eleventh Report of Session 2014-15. http://www.publications.parliament.uk/pa/cm201415/cmselect/cmhaff/202/ 202 .pdf, accessed 28 June 2016.

Kerr, P. and Hayton, R. (2015) Whatever happened to Conservative Party modernisation? British Politics 10(2): 114-130.

Kickert, W. (2012) State responses to the fiscal crisis in Britain, Germany and the Netherlands. Public Management Review 14(3): 299-309.

Klijn, E. H. and Koppenjan, J. (2016) Governance Networks in the Public Sector. London and New York : Routledge.

Lane, J. (2006) Public Administration and Public Management: The Principal-Agent Perspective. London: Routledge.

Lansley, A. (2006) The Conservative vision for the NHS. In: M. Tempest (ed.) The Future of the NHS. Unite Kingdom: XPL Publishing, pp. 19-26.

Lister, S. and Rowe M. (2014) Electing police and crime commissioners in England and Wales: prospecting for the democratisation of policing. Policing and Society 25(4): 358-377. 
Loughran, M. (2018). Detention under section 136: Why is it increasing? Medicine, Science and the Law 58(4): 268-274.

Lowndes, V. and Gardner, A. (2016) Local governance under the Conservatives: superausterity, devolution and the 'smarter state'. Local Government Studies 42(3): 357-375.

Lowndes, V. and McCaughie, K. (2013) Weathering the perfect storm? Austerity and institutional resilience in local government. Policy \& Politics 41(4): 533-549.

Lowndes, V. and Lemprière, M. (2018) Understanding Variation in Processes of Institutional Formation. Political Studies 66(1): 226-244.

Heslin, M., and Lynne Callaghan, Barbara Barrett, Susan Lea, Susan Eick, John Morgan, Mark Bolt, Graham Thornicroft, Diana Rose, Andrew Healey and Anita Pate (2016). Costs of the police service and mental healthcare pathways experienced by individuals with enduring mental health needs. British Journal of Psychiatry. DOI: 10.1192/bjp.bp.114.159129

Marsh, D., Richards, D., and Smith, M. (2003) Unequal plurality: Towards an asymmetric power model of British politics. Government and Opposition 38(3): 306-332.

Mattheys, K. (2015) The Coalition, austerity and mental health. Disability \& Society 30(3): $475-478$.

Morris, N. (2015) General Election 2015: Further planned cuts to police budgets under Tories, says Theresa May. The Independent, 27 April 2015 
http://www.independent.co.uk/news/uk/politics/generalelection/general-election-2015-furtherplanned-cuts-to-police-budgets-under-tories-says-theresa-may- 10208096.html, accessed 18 June 2016.

Moth, R., Greener, J. and Stoll, T. (2015) Crisis and resistance in mental health services in England. Critical and Radical Social Work 3(1): 89-101.

Newburn, T. (2015) What's happening to police numbers? BBC News, 24 November 2015 http://www.bbc.co.uk/news/uk-34899060, accessed 28 June 2016.

NHS Confederation (2015). Mental Health and Policing: Improving Crisis Care. Retrieved from http://www.nhsconfed.org/ /media/173E13442E2C470997D3F87370211F7E.ashx (Accessed 28 June 2016).

O’Driscoll, M-L. (2007) Taking the wait off: An examination of the influence of policy networks in a case where local policy was formulated and implemented to reduce protracted waiting for orthopaedic services. In: A. Hann (ed.) Health Policy and Politics. Aldershot: Ashgate, pp. 123-138.

Office of the Deputy Prime Minister (2014) Nick Clegg holds first mental health taskforce meeting. Retrieved from https://www.gov.uk/government/news/nick-clegg-holds-first-mentalhealth-taskforce-meeting (accessed 18 July 2016) 
Office of the Deputy Prime Minister (2015) Deputy prime minister launches search for mental health heroes. Retrieved from https://www.gov.uk/government/news/deputy-prime-ministerlaunches-search-for-mental-health-heroes (accessed 18 July 2016)

Ovretveit, J., Mathias, P. and Thompson, T. (1997) Interprofessional Working for Health and Social Care. Basingstoke: Palgrave.

Page, R.M. (2011) The emerging blue (and orange) health strategy: Continuity or change? In: S. Lee and M. Beech (eds.) The Cameron-Clegg Government: Coalition Politics in an Age of Austerity. Basingstoke: Palgrave Macmillan, pp. 89-104.

Parker, G (2015) Britons back further welfare cuts, says poll. Financial Times, 20 April 2015. http://www.ft.com/cms/s/0/a548291c-e763-11e4-a01c-00144feab7de.html, accessed 18 June 2016.

Parliament (2015) Police reform: Key issues for the 2015 Parliament. Retrieved from https://www.parliament.uk/business/publications/research/key-issues-parliament2015/justice/police-reform/ (accessed 18 June 2016).

Parliament (2016) Police numbers: Social Indicators page. http://researchbriefings.parliament.uk/ResearchBriefing/Summary/SN02615, accessed 18 June 2016).

Paterson C, and Pollock, E. (2016) Editorial: Global shifts in the policing of mental ill health. Policing: A Journal of Policy and Practice 10(2): 91-94. 
Paton, F., Wright, K., Ayre, N., Dare, C., Johnson, S., Lloyd-Evans, B., et al. (2016) Improving outcomes for people in mental health crisis: a rapid synthesis of the evidence for available models of care. Health Technology Assessment 20 (3), DOI: 10.3310/hta20030.

Pilgrim, D., Ramon, S. (2009) English mental health policy under New Labour. Policy \& Politics 37(2): 273-288.

Prime Minister's Office (2015) PM on plans for a seven-day NHS. Retrieved from https://www.gov.uk/government/speeches/pm-on-plans-for-a-seven-day-nhs (Accessed 18 July 2016).

Quinn, B., Laville, S. and Duncan, P. (2016) Mental Health crises take huge and increasing share of police time. The Guardian, 27 January 2016, https://www.theguardian.com/uknews/2016/jan/27/mental-health-crisis-huge-increasing-share-police-time-40, accessed 28 June 2016.

Reiner, R. (2016) Power to the people? A social democratic critique of the Coalition Government's police reforms. In: S. Lister M. Rowe (eds.) Accountability of Policing. Abingdon: Routledge, pp. 132-149.

Rex, B. (2019) Which museums to fund? Examining local government decision-making in austerity. Local Government Studies, Online First, DOI: 10.1080/03003930.2019.1619554. 
Rhodes, R. A. W. (1988) Beyond Westminster and Whitehall: The Sub-Central Governments of Britain. London: Allen and Unwin.

Rhodes, R. A. W. (1997) Understanding Governance: Policy Networks, Governance, Reflexivity and Accountability. Buckingham: Open University Press.

Richards, D., Smith, M. and Hay, C. (2014) Institutional Crisis in 21st Century Britain. Basingstoke: Palgrave Macmillan.

Richardson, L., Durose, C. and Dean, R. J. (2018). Why decentralize decision making? English local actors' viewpoints. Governance 32(1): 159-176.

Richmond Fellowship (2015). Annual Review 2015: Inspiring individuals to recovery nationwide. Retrieved from http://www.richmondfellowship.org.uk/wpcontent/uploads/2016/02/Recovery-Focus-AR-2015-online.pdf (Accessed 19 July 2016)

Royal College of Psychiatrists (2010) No Health Without Mental Health. Retrieved from http://www.rcpsych.ac.uk/pdf/No\%20Health\%20\%20\%20the\%20evidence_\%20revised\%20 May \%2010.pdf (accessed 28 June 2016).

Shaw, D. (2015) Police forces must reform to survive cuts, says new chief. BBC News, 20 July, http://www.bbc.co.uk/news/uk-33599230, accessed 28 June 2016.

Smith, M. (2010) From big government to big society: Changing the state-society balance. Parliamentary Affairs 63(4): 818-833. 
Smith, M., Richards, D., Geddes, A. and Mathers, H. (2011) Analysing policy delivery in the United Kingdom: the case of street crime and anti-social behaviour. Public Administration 89(3): 975-1000.

Smith, M., and Jones, R. (2015) From big society to small state: Conservatism and the privatisation of government. British Politics 10(2): 226-248.

Squires, P. (2008) The politics of anti-social behaviour. British Politics 3(3): 300-323.

Stoker, G. (2011) Was local governance such a good idea? A global comparative perspective. Public Administration 89(1): 15-31.

Tempest, M. (2006) The Future of the NHS. Unite Kingdom: XPL Publishing.

Thomas, A. and Forrester-Jones, R. (2019). Understanding the changing patterns of behaviour leading to increased detentions by the police under Section 136 of the Mental Health Act 1983. Policing: A Journal of Policy and Practice 13(2): 134-146.

Thelen, K. (2009) Institutional change in advanced political economies. British Journal of Industrial Relations 47(3): 471-498.

Travers, T. (2015) The Coalition and society: Home affairs and local government. In: A. Seldon, and M. Finn (eds.) The Coalition Effect 2010-2015, Cambridge: Cambridge University Press, pp. 228-256. 
Wilson, D. and Game, C. (2011) Local Government in the United Kingdom. Basingstoke and New York: Palgrave Macmillan.

YouGov (2013). Mentally ill 'most discriminated against group in Britain'. Retrieved from https://yougov.co.uk/news/2013/10/01/mentally-ill-most-discriminated-against/, accessed 01 November 2016. 